\title{
The Feminism in the Eye of Jane Austen
}

\author{
Yue Wu \\ Beijing University of Chinese Medicine Dongfang College
}

\begin{abstract}
In this paper the author first makes an analysis of the feminism hinted in Jane Austen, she implicitly expresses her discontentment of a popular view of her day-women were born less talented than men and women were less rational than men. As is known, nearly every literary works has its own social or political background. Pride and Prejudice is no exception. So the writing about feminism in this novel, namely the status of women, legalities of marriage, women's education, moral standard upon sex as well as Jane Austen's own life experience. It was thought that Austen was a romance writer who taught virtue in her prose.
\end{abstract}

Keywords: Feminism, Jane Austen.

\section{The Development of Feminism}

Feminism, also known as the feminist movement, its contents are mainly about women' the main political movements and social theory. In the last two centuries, as the result of extensive use, feminism was given a new meaning. In short, feminism is women's claim to acquire full rights as human beings.

The theory of feminism is about to: in the first place, describing genders inequality or the situation of women, in the second place, explaining the reason in the female 'point of view, last but not the least, seeking to the improved road.

Then is the discussion how to eliminate the power of domination and dependency relations, and to establish new culture of equality and coexistence, a new society. According to the research, "feminism" is a word from French in 1880 , Hubertine Auclert (1848-1914) first proposed the term in1890s, the French women's groups or women's publication often cited this word, to express the women's equal rights

The well-known woman activist Marie Gauze on behalf of her club made the first women's rights "Declaration of the Rights of Women" advocated equal rights to obtain freedom and equality. But she was later killed in the French Revolution, women's clubs also be dissolved, but the women did not give up their rights.

Pride and Prejudice, similar to other Jane Austen's novels, is written in gentle or Horacian satire. The main object of Jane's satire in the novel is the mercenary and the ignorance of the people, a common criticism of the 18 th century. Characters in the novel which best carries these qualities are Mrs. Bennet, a foolish woman who talks too much and is obsess with getting her daughters married; Lydia Bennet, the youngest of the Bennet daughter who is devoted to a life of dancing, fashions, gossips and flirting; and Mr. Williams Collins, the silly and conceited baboon who is completely stupefy by Lady Catherine in every aspect of his life that he has forgotten his own morals and duty. The tone of the novel is light, satirical, and vivid. Scenes such as Mr. Collins proposal to Elizabeth, and Lady Catherine visits to Lizzy at Longbourn, provide comic relief to the reader while at the same time revealing certain characteristics of the characters. For example, Lydia's lack of common sense and responsibility is revealed when she takes pride in being the first Bennet girl to be married. Lydia does not take into consideration the circumstance of her marriage, the personality of her husband, or the prospects of their marriage for the future. Elizabeth Bennet's ability to laugh off her misfortunate and to continue to be optimistic, considering her situation, also contributes to the tone of the novel. The point of view in Pride and Prejudice is limited omniscient; the story is told through Elizabeth, but not in first person. As a result, the mood of the novel lacks dramatic emotions. The atmosphere is intellectual and cold; there is little descriptions of the setting. The main actions of the novel are the interactions between opinions, ideas, and attitudes, which weaves and advances the plot of the novel. The emotions in the novel are to be perceived beneath the surface of the story and are not to be expressed to the readers directly. Jane's power of subtle discrimination and shrewd perceptiveness is revealed in Pride and Prejudice; she is able to convey such a complex message using a simple, yet witty, style.

The main subject in the novel is stated in the first sentence of the novel: "It is a truth universally acknowledged that a single man in possession of a good fortune must be in want of a wife." In this statement, Jane has cleverly done three things: she has declared that the main subject of the novel will be courtship and marriage, she has established the humorous tone of the novel by taking a simple subject to elaborate and to speak intelligently of, and she has prepared the reader for a chase in the novel of either a husband in search of a wife, or a woman in pursuit of a husband. The first line also defines Jane's book as a piece of literature that connects itself to the 18 th century period. Pride and Prejudice is 18th century because of the emphasis on man in his social environment rather than in his individual conditions. The use of satire and wit, a common form of 18 th century literature, also contributes to label the book as 18th century. However, because Jane Austen had allowed personal feelings of the characters to be expressed in her work, she can also be classified as Romantic. In the figure of Elizabeth, Jane Austen shows passion attempting to find a valid mode of existence in society. Passion and reasons also comes together in the novel to show that they are complementary of marriage.

There are seven different marriages presented in the novel. Excluding the Gardiner and the Lucas, the remaining five marriages contrast each other to reveal Jane's opinions and thoughts on the subject of marriage.

The marriage between Darcy and Elizabeth reveals the characteristics which constitutes a successful marriage. One 
of these characteristics is that the feeling cannot be brought on by appearances, and must gradually develop between the two people as they get to know one another. In the beginning, Elizabeth and Darcy were distant from each other because of their prejudice. The series of events which they both experienced gave them the opportunity to understand one another and the time to reconcile their feelings for each other. Thus, their mutual understanding is the foundation of their relationship and will lead them to a peaceful and lasting marriage. This relationship between Elizabeth and Darcy reveals the importance of getting to know one's partner before marrying. The marriage between Jane Bennet and Bingley is also an example of successful marriage. Jane Austen, through Elizabeth, expresses her opinion of this in the novel: “....really believed all his [Bingley] expectations of felicity, to be rationally founded, because they had for basis the excellent understanding, and super-excellent disposition of Jane, and a general similarity of feeling and taste between her and himself.’'[2]

However, unlike Darcy and Elizabeth, there is a flaw in their relationship. The flaw is that both characters are too gullible and too good-hearted to ever act strongly against external forces that may attempt to separate them:

"You [Jane and Bingley] are each of you so complying, that nothing will ever be resolved on; so easy, that every servant will cheat you; and so generous, that you will always exceed your income."[3]

Obviously, Lydia and Wickham's marriage is an example of a bad marriage. Their marriage was based on appearances, good looks, and youthful vivacity. Once these qualities can no longer be seen by each other, the once strong relationship will slowly fade away. As in the novel, Lydia and Wickham's marriage gradually disintegrates; Lydia becomes a regular visitor at her two elder sister's homes when "her husband was gone to enjoy himself in London or Bath." Through their relationship, Jane Austen shows that hasty marriage based on superficial qualities quickly cools and leads to unhappiness.

Although little is told of how Mr. Bennet and Mrs. Bennet got together, it can be inferred by their conversions that their relationship was similar to that of Lydia and Wickham - Mr. Bennet had married a woman he found sexually attractive without realizing she was an unintelligent woman. Mrs. Bennet's favoritism towards Lydia and her comments on how she was once as energetic as Lydia reveals this similarity. Mr. Bennet's comment on Wickham being his favorite son-in-law reinforces this parallelism. The effect of the relationships was that Mr. Bennet would isolate himself from his family; he found refugee in his library or in mocking his wife. Mr. Bennet's self-realization at the end of the novel in which he discovers that his lack of attention towards his family had lead his family to develop the way they are, was too late to save his family. He is Jane Austen's example of a weak father. In these two latter relationships, Austen shows that it is necessary to use good judgment to select a spouse, otherwise the two people will lose respect for each other.

The last example of a marriage is of a different nature than the ones mentioned above. The marriage between Mr. Collins and Charlotte is based on economics rather than on love or appearance. It was a common practice during Austen's time for women to marry a husband to save herself from spinsterhood or to gain financial security. However, Jane Austen viewed this as a type of prostitution and disapproved of it. In Pride and Prejudice, Jane Austen dramatizes this form of women inequality and show that women who submits themselves to this type of marriage will have to suffer in tormenting silence as Charlotte does:

"When Mr. Collins said any thing of which his wife might reasonably be ashamed, which certainly was not unseldom, she [Elizabeth] would involuntarily turned her eye on Charlotte. Once or twice she could discern a faint blush; but in general Charlotte wisely did not hear.'[4]

These five marriages contributes to the theme that a happy and strong marriage takes time to build and must be based on mutual feeling, understanding, and respect. Hasty marriages acting on impulse, and based on superficial qualities will not survive and will lead to inevitable unhappiness.

\section{Jane Austen' Contempt for Secular Prejudice}

\subsection{The Advanced Sense of Equality between Men and Women}

As an authoress in the eighteenth century in England, Jane Austen had a sensible view on marriage. In her six novels, she described various kinds of characters and their everyday life. All of the characters had different experiences, and acted in different ways. However, they had a common pursuit, that's, marriage. This paper is to find what Austen's view on marriage was. In describing the characters' everyday life and one marriage after another, Austen expressed her sensible view on marriage clearly. In her opinion, money was essential to a marriage while the equality in social status would increase the possibility of the marriage, but what affected the marriage most were manners. According to her, it was the good manners that united the heroes and heroines. Compared with the social view on marriage nowadays, Austen's view on marriage may be restricted. However, during her lifetime, her view was so advanced that it was not accepted widely. In a word, Jane Austen was a brilliant writer who had an advanced and sensible view on marriage. Jane Austen was brilliant as she had an advanced view on marriage. In her opinion, a marriage needed enough money to afford everyday life; the equality in social status would make the marriage more possible, whereas the equality in idea affected the extent of happiness in it. She highly appreciated good manners and considered manners as the most important factor in conditioning a marriage. In describing various kinds of characters and their marriages, she showed her opposition to the money-oriented marriage and expressed a strong discontent with the low social status of the women in her time. As an authoress in the eighteenth century, her view on marriage was much more remarkable than most of the male authors during her lifetime. 


\subsection{The Advanced Sense of Equality between Men and Women of Jane Austen}

Jane Austen was born in Steventon, Hampshire, where her father, Rev. George Austen, was a rector. She was the second daughter and seventh child in a family of eight. The Austens did not lose a single one of their children. Cassandra Leigh, Jane's mother, fed her infants at the breast a few months, and then sent them to a wet nurse in a nearby village to be looked after for another year or longer.

The first 25 years of her life Jane spent in Hampshire. On her father's unexpected retirement, the family sold off everything, including Jane's piano, and moved to Bath. Jane, aged twenty-five, and Cassandra, her elder sister, aged twenty-eight, were considered by contemporary standards confirmed old maid, and followed their parents. Torn from her friends and rural roots in Steventon, Austen abandoned her literary career for a decade.

Jane Austen was mostly tutored at home, and irregularly at school, but she received a broader education than many women of her time. She started to write for family amusement as a child. Her parents were avid readers; Austen's own favorite poet was Cowper. Her earliest-known writings date from about 1787 . Very shy about her writing, she wrote on small pieces of paper that she slipped under the desk plotter if anyone came into the room. In her letters she observed the daily life of her family and friends in an intimate and gossipy manner: "James danced with Alethea, and cut up the turkey last night with great perseverance. You say nothing of the silk stockings; I flatter myself, therefore, that Charles has not purchased any, as I cannot very well afford to pay for them; all my money is spent in buying white gloves and pink Persian." (Austen in a letter to her sister Cassandra in 1796)

Rev. George Austen supported his daughter's writing aspirations, bought her paper and a writing desk, and tried to help her get a publisher. After his death in 1805, she lived with her sister and hypochondriac mother in Southampton. In July 1809 they moved to a large cottage in the village of Chawton. This was the place where Austen felt at home. She never married, she never had a room of her own, but her social life was active and she had suitors and romantic dreams. With Tom Lefroy, whom she met a few times in 1796, she talked about Fielding's Tom Jones. They shared similar sense of ironic humor and Austen was undeniably attracted to him. James Edward Austen-Leigh, her nephew, wanted to create another kind of legend around her and claimed that "of events her life was singularly barren: few changes and no great crises ever broke the smooth current of its course... There was in her nothing eccentric or angular; no ruggedness of temper; no singularity of manner..." Austen's sister Cassandra also never married. One of her brothers became a clergyman, two served in the navy, one was mentally retarded. He was taken care of a local family.

Jane Austen was well connected with the middling-rich landed gentry that she portrayed in her novels. In Chawton she started to write her major works, among them SENSE AND SENSIBILITY, the story of the impoverished Dashwood sisters, Marianne and Elinor, who try to find proper husbands to secure their social position. The novel was written in 1797 as the revision of a sketch called Elinor and Marianne, composed when the author was 20. According to some sources, an earlier version of the work was written in the form of a novel in letters, and read aloud to the family as early as 1795.

Austen's heroines are determined to marry wisely and well, but romantic Marianne of Sense and Sensibility is a character, who feels intensely about everything and loses her heart to an irresponsible seducer. "I could not be happy with a man whose taste did not in every point coincide with my own. $\mathrm{He}$ must enter into all my feelings; the same with books, the same music must charm us both." Reasonable Elinor falls in love with a gentleman already engaged. "I have frequently detected myself in such kind of mistakes," said Elinor, "in a total misapprehension of character in some point or another: fancying people so much more gay or grave, or ingenious or stupid than they really are, and I can hardly tell why or in what the deception originated. Sometimes one is guided by what they say of themselves, and very frequently by what other people say of them, without giving oneself time to deliberate and judge."

When Marianne likes to read and express her feelings, Elinor prefers to draw and design and be silent of his desires. They are the daughters of Henry Dashwood, whose son, John, from a former marriage. After his death, John inherits the Norland estate in Sussex, where the sisters live. John's wife, the greedy and selfish Fanny, insists that they move to Norland. The impoverished widow and her daughters move to Barton Cottage in Devonshire. There Marianne is surrounded by a devious heartbreaker Willoughby, who has already loved another woman. Elinor becomes interested in Edward Ferrars, who is proud and ignorant. Colonel Brandon, an older gentleman, doesn't attract Marianne. She is finally rejected by Willoughby. "Marianne Dashwood was born to an extraordinary fate. She was born to discover the falsehood of her own opinions, and to counteract, by her conduct, her most favorite maxims."

In all of Austen's novels her heroines are ultimately married. Pride and Prejudice described the clash between Elisabeth Bennet, the daughter of a country gentleman and an intelligent young woman, and Fitzwilliam Darcy, a rich aristocratic landowner. Their relationship starts from dislike, but Darcy becomes intrigued by her mind and spirit. At last they fall in love and are happily united. Austen had completed the early version of the story in 1797 under the title "First Impressions". The book went to three printings during Austen's lifetime. In 1998 appeared a sequel to the novel, entitled Desire and Duty, written by Teddy F. Bader, et al. It followed the ideas Jane Austen told her family.

Jane Austen focused on middle-class provincial life with humor and understanding. She depicted minor landed gentry, country clergymen and their families, in which marriage mainly determined women's social status. Most important for her were those little matters, as Emma says, "on which the daily happiness of private life depends." Although Austen restricted to family matters, and she passed the historical events of the Napoleonic wars, her wit and observant narrative touch has been inexhaustible delight to readers. Of her six great novels, four were published anonymously during her 
lifetime. Austen also had troubles with her publisher, who wanted to make alterations to her love scenes in Pride and Prejudice. In 1811 he wrote to Thomas Egerton: "You say the book is indecent. You say I am immodest. But Sir in the depiction of love, modesty is the fullness of truth; and decency frankness; and so I must also be frank with you, and ask that you remove my name from the title page in all future printings; 'A lady' will do well enough." At her death on July 18, 1817 in Winchester, at the age of forty-one, Austen was writing the unfinished SANDITON. She managed to write twelve chapters before stopping in March 18, due to her poor health. Jane Austen was buried in Winchester Cathedral, near the centre of the north aisle. "It is a satisfaction to me to think that [she is] to lie in a Building she admired so much," Cassandra Austen wrote later. Cassandra destroyed many of her sister's letters; one hundred sixty survived but none written earlier than her tenth birthday.

Jane Austen's brother Henry made her authorship public after her death. Emma had been reviewed favorably by Sir Walter Scott, who wrote in his journal of March 14, 1826: "[Miss Austen] had a talent for describing the involvements and feelings and characters of ordinary life which is to me the most wonderful I have ever met with. The Big Bow-Wow strain I can do myself like any now going; but the exquisite touch, which renders ordinary commonplace things and characters interesting, from the truth of the description and the sentiment, is denied to me." Charlotte Brontë and E.B. Browning found her limited, and Elizabeth Hardwick said: "I don't think her superb intelligence brought her happiness." It was not until the publication of J.E. Austen-Leigh's Memoir in 1870 that a Jane Austen cult began to develop. Austen's unfinished Sanditon was published in 1925.

\section{Conclusion}

When reading Jane Austen's novel Pride and Prejudice most people tend to enjoy the quiet irony and her simple delicate analysis of character. They usually don't pay much attention to the implicit feminism conveyed by this great woman writer of Romantic Period (1798-1832).

This was not the case. While it may be true that Austen was a romance writer, it was not the way critics had once believed. Instead of exalting the value of tradition and virtue in her prose, Austen defied it and made a case for feminine rights. Whether we see Austen as a feminist because we are looking for evidence in her text or because she truly was a feminist is something that we may never be able to discern. Complex Heroines-Elizabeth, Catherine and Elinor. While most of Austen's characters did want to marry; they always wanted to choose their own suitors and marry for love which is something that was unheard of during Austen's lifetime.

Elizabeth Bennet, in Pride and Prejudice, "who will be dependant on her family and at the mercy of Mr. Collins who holds the entail to the family house if she never marries, only wants to marry if she can find 'the deepest love'"[28]. Elizabeth was a very intelligent character, but it was not only the smart females that held this sort of strong feminine notion about marrying for love.
Austen was not outright in her feminism and if you weren't looking for it, you might not have noticed the stances she took. She was well known for writing about young women who only had interest in marriage, and she was often underestimated because of this. If you analyze her work you will find her subtle feminist tendencies.

\section{References}

[1] Austen, Jane. Pride and Prejudice. Boston: Houghton Mifflin, 1956. p2.

[2] Bower, Reuben. The Field of Light. New York: Oxford University, Pr., 1951. p4.

[3] Conrad Peter. "Pride and Prejudice." (1997): Online. Internet. 30 March. p5.

[4] Daiches, David. A Critical History of English Literature. 2 vols. New York. p6.

[5] Ronald Press, The Penguin Companion to English Literature. 1960. p10.

[6] Britain: English History. McGraw-Hill, 1971.p10.

[7] Magill, Frank. Masterplots. New Jersey: Salem Press, 1976. p10.

[8] Tucker, Martin. Moulton's Library of Literary Criticism of English and American. p10.

[9] Authors Mark. New York: Frederick Ungar, 1966. p11.

[10] Austen Jane. Pride and Prejudice. The Book League of America, 1985. p11.

[11] Maggie Lane, Guo Jing, translated. The World of Jane Austen. Hainan Publishing House, 2004. p11.

[12] Xi Huiling. Western Feminism and Criticism of Chinese Women Writers. Shanghai Academy of Social Sciences Press, 2003. p11.

[13] $\mathrm{Xu}$ Yingguo. Comparison of Chinese and English Women's Literature and Feminist Literature. Foreign Literature Studies, 1997. p11.

[14] Qiu Yin. Austin and British Women's Literature. Journal of Shanghai University 1996. p11.

[15] Yang Lixin. On Jane Austen's Feminine Consciousness from the Structure of Pride and Prejudice. Journal of Nanjing Normal University, 1998. p11.

[16] Kang Zhengguo. A Review of Feminist Literature Criticism. Literary Criticism, 1998. p11.

[17] Wu Weihua. An Analysis of the Female Writing Standpoint of Pride and Prejudice. Foreign Literature Studies, 2000. p13.

[18] Song Jianhua. The Feminine Consciousness of Pride and Prejudice. Journal of Dalian University, 2001. p13.

[19] Zhang Jingyuan. Contemporary Feminist Literature Criticism. Peking University Press, 1992. p14.

[20] [UK] Jane Austen, Li Changshuan, translated. Pride and Prejudice. Shanghai: Foreign Language Teaching and Research Press, 1997. p14.

[21] Jane Austen. Pride and Prejudice. Shanghai: Shanghai Literature and Art Publishing House, 1990. p14.

[22] Zhang Dingquan, Wu Gang. A New Concise History of English Literature. Shanghai: Shanghai Foreign Language Education Press, 2002. p14.

[23] Zhu Liyuan. Contemporary Western Literary Theory. Shanghai: East China Normal University Press, 2005. p14.

[24] Zhang Jingyuan. Contemporary Feminism and Literary Criticism. Beijing: Peking University Press, 1995.p14. 
[25] Zhang Xiaojin. On the Female Theme Consciousness in "Pride and Prejudice". Film Literature, 2008, (12): 97. p16. 